\title{
RELATIONSHIP BETWEEN SUBJECTIVE WELL-BEING AND COMMITMENT TO SUCCESS OF STUDENTS
}

\author{
Mikaelian M. A., Hakobyan N. M. (Armenian State Pedagogical University, \\ Yerevan, Armenia) \\ marine.mikaelian@ysu.am,nar.hakobyan.7@mail.ru \\ 乙tiplujugưuน uर्vu. 31.07.2021 \\ 9pmpunuर्जuध uर्vu. 07.08.2021

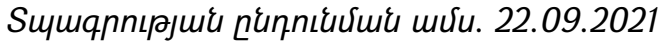

\begin{abstract}
The aim of the study is to investigate the relationship between subjective well-being and the pursuit of success in junior and senior students. The results show that the highest indicators of subjective wellbeing of students are expressed in the scales of peace, health, happiness, existence, which is obviously related to the current situation in Armenia caused by the war in Artsakh and the coronavirus pandemic. Psychological, physical and mental well-being among students is preferable to social and material well-being. Students are highly motivated to succeed in achieving the desired goal. Senior students, unlike undergraduate students, are more satisfied with all aspects of life. Senior students are more motivated to succeed than junior students. Students with a high level of success motivation have a higher level of life satisfaction.
\end{abstract}

Keywords: subjective well-being, striving for success, student, life satisfaction.

DOI: https://doi.org/10.46991/SBMP/2022.5.1.073

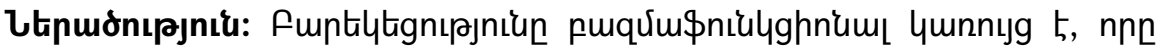

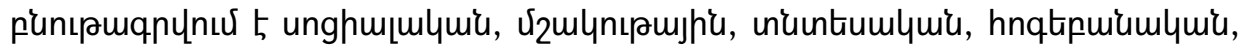

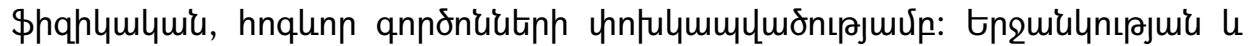

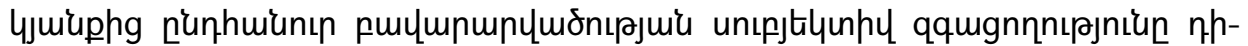

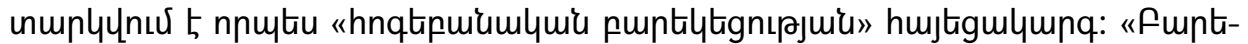

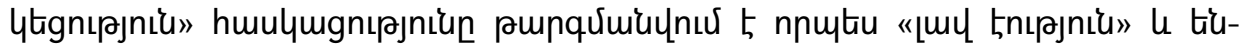

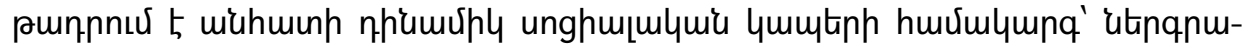

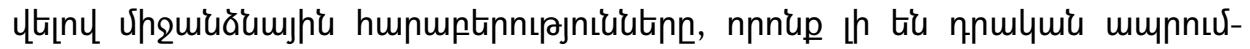
utipny [7]:

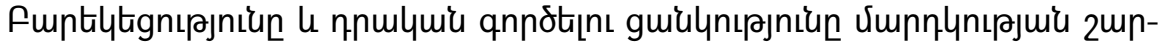

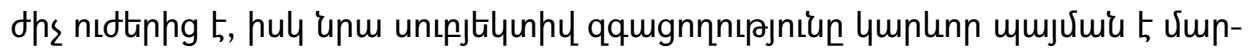

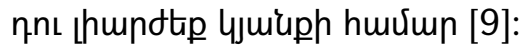

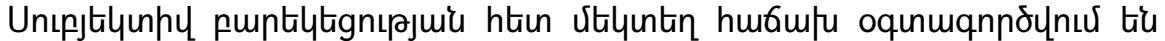

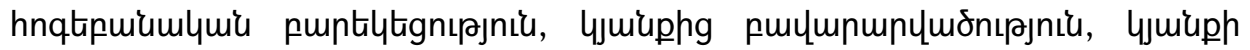
nnuly huulumgnıpjniuktinn [1]: 


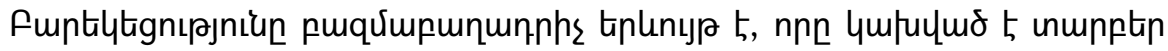

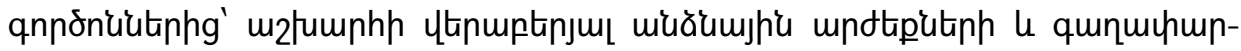

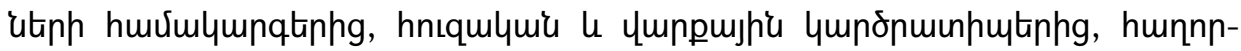

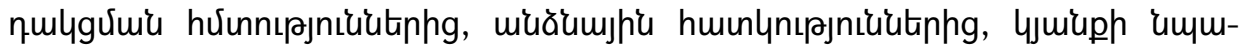

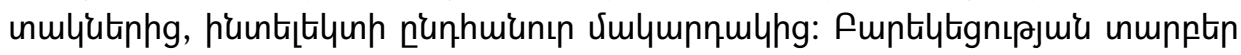

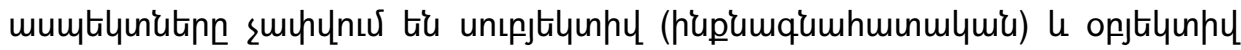

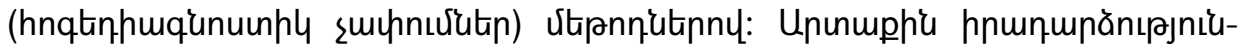

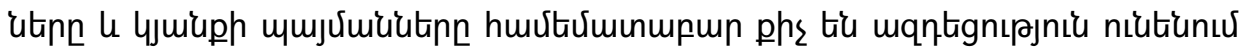

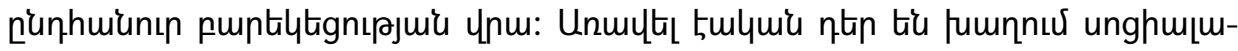

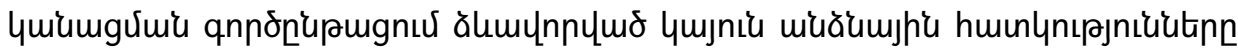

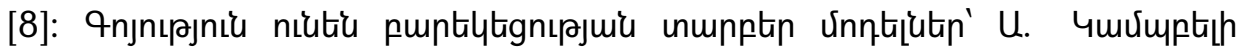

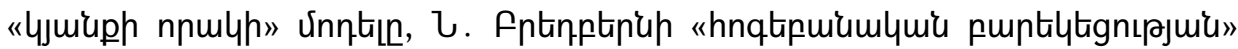

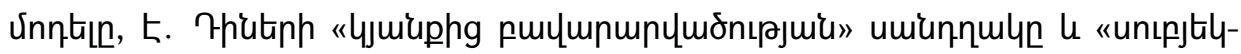

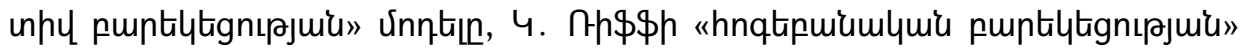

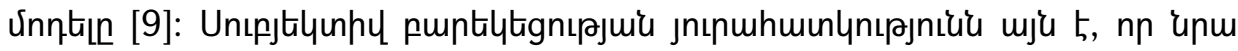

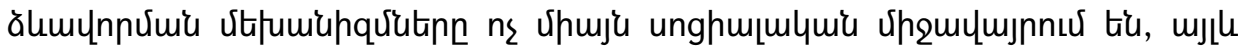

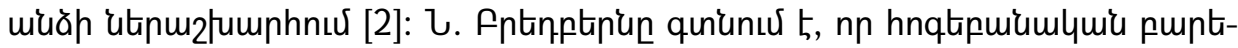

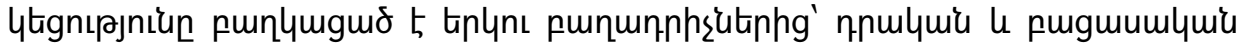

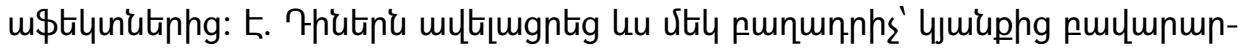

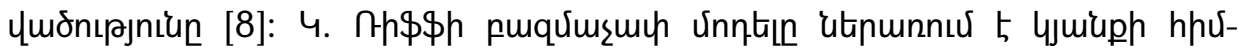

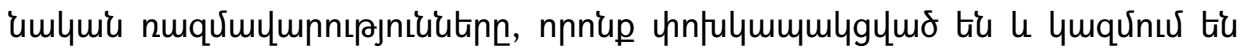

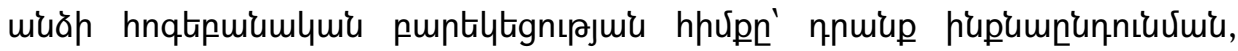

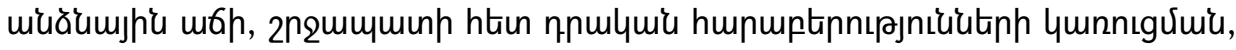

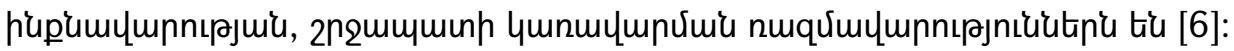

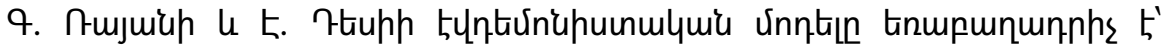

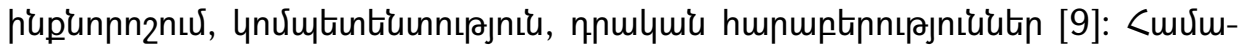

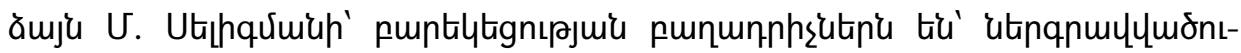

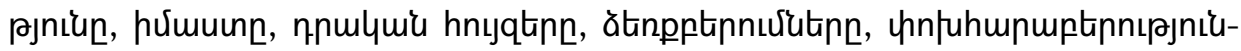

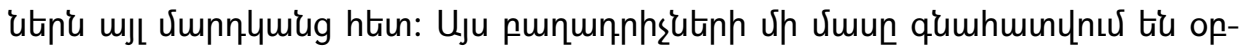

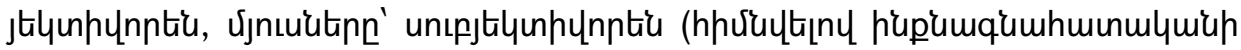

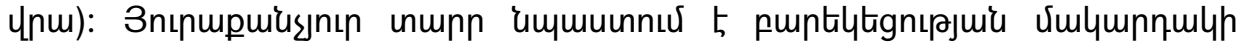

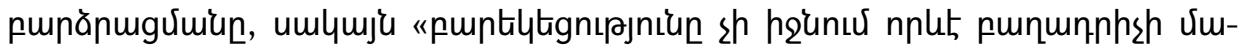

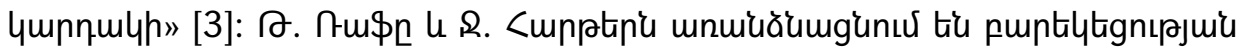

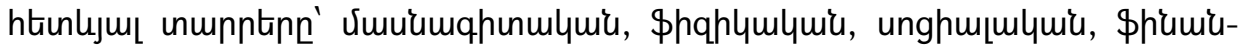

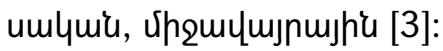

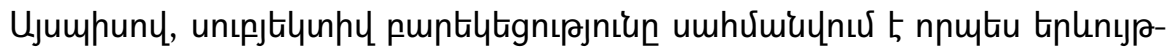

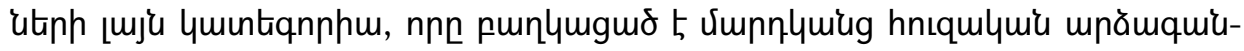

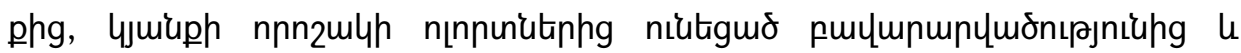

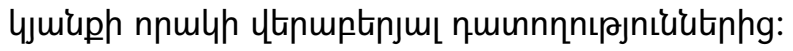




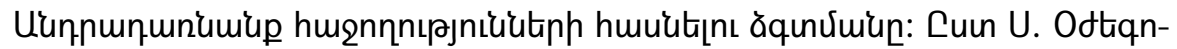

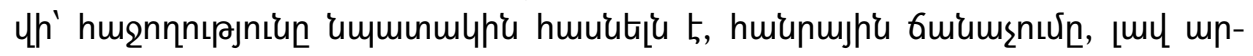

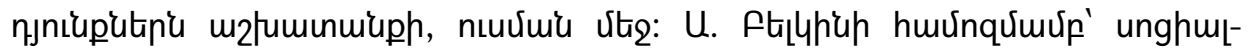

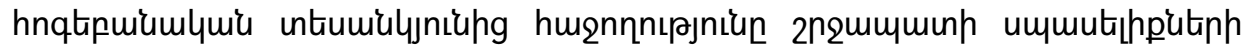

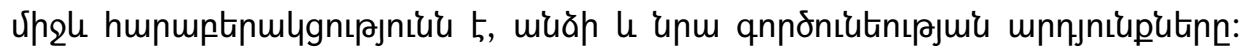

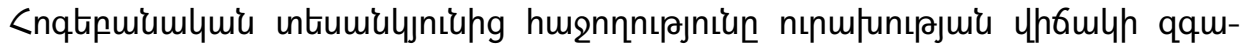

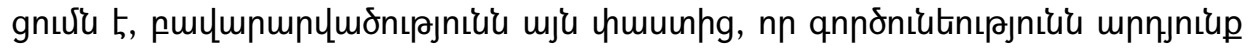

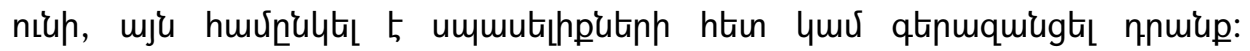

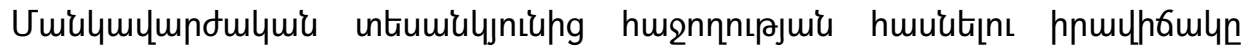

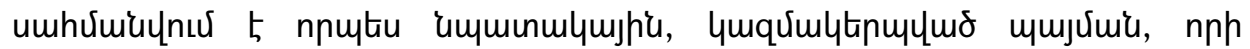

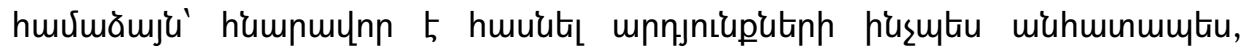

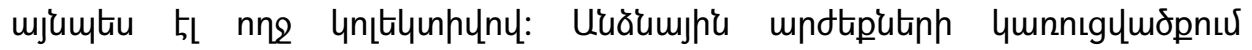

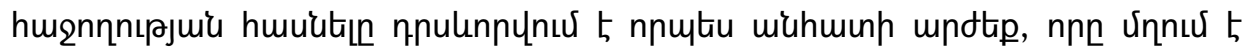

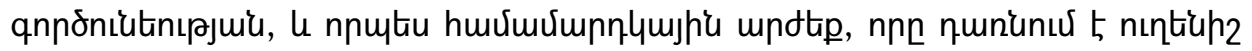
[4]:

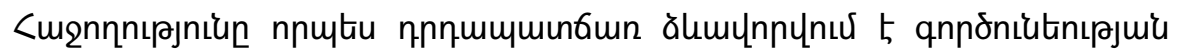

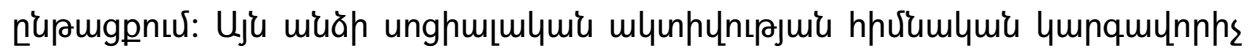

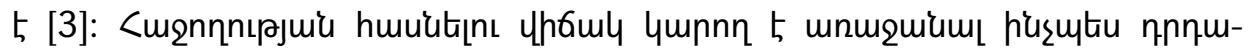

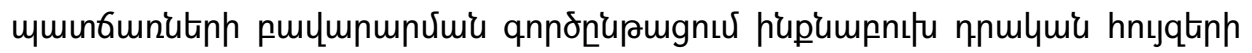

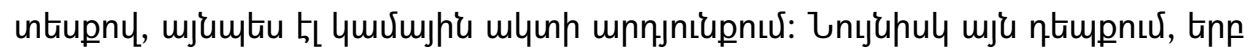

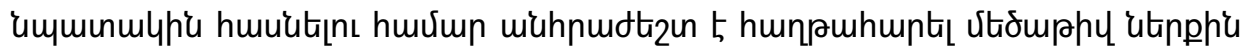

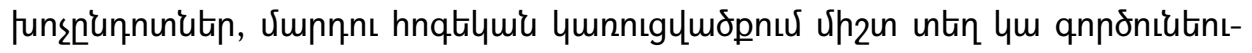

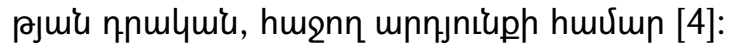

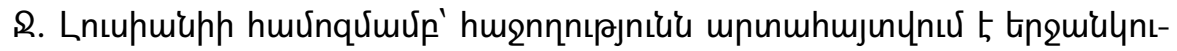

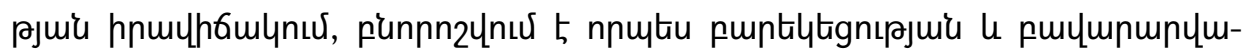

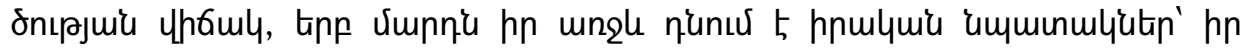

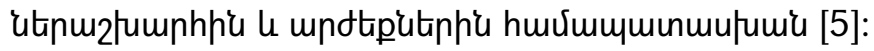

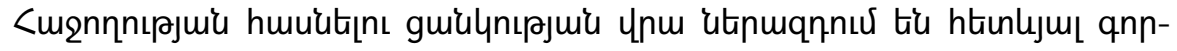

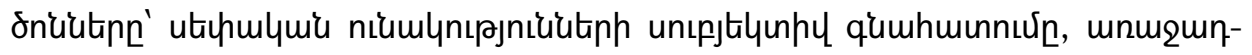

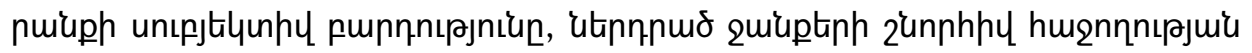

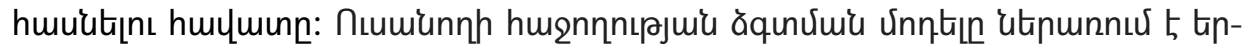

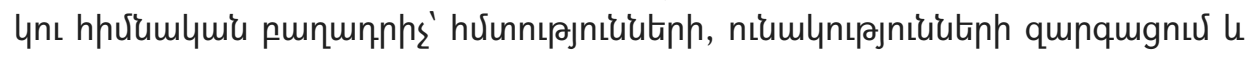

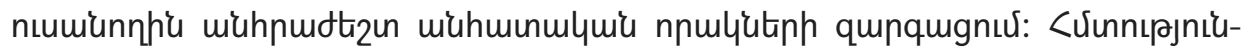

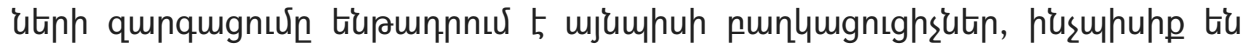

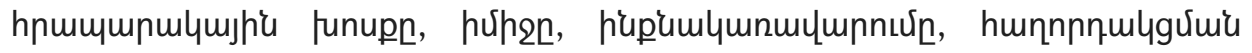

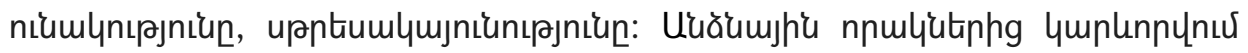

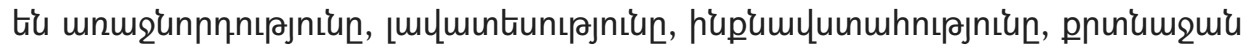

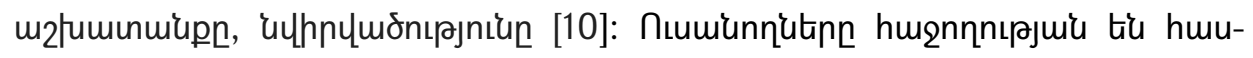

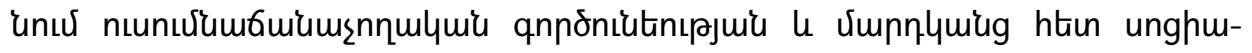

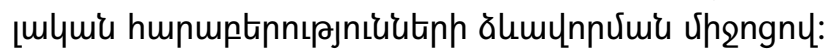




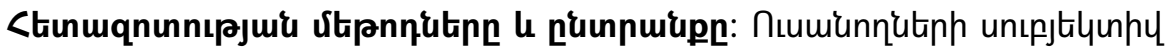

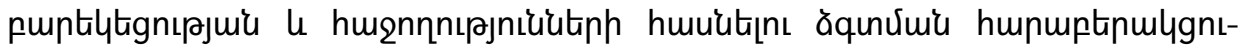

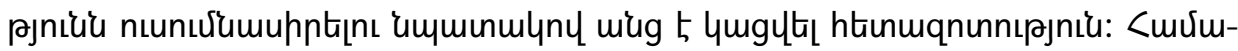

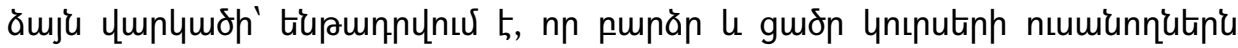

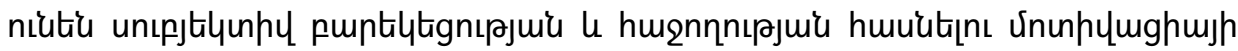

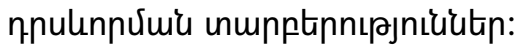

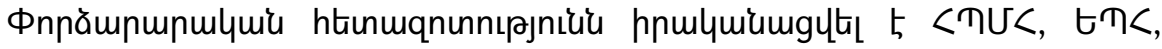

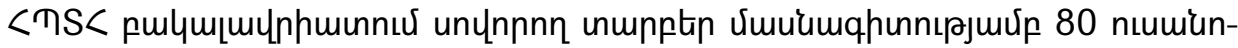

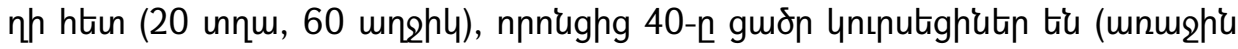

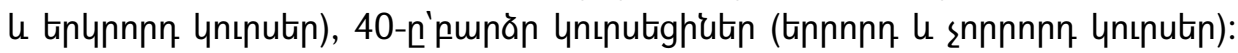

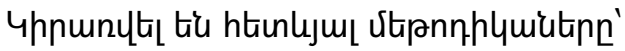

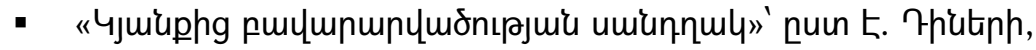

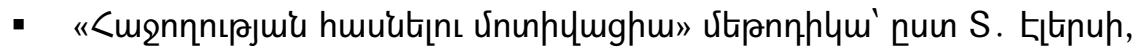

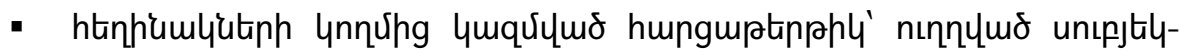

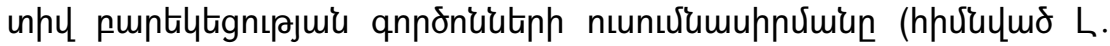

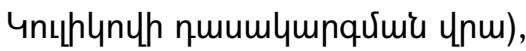

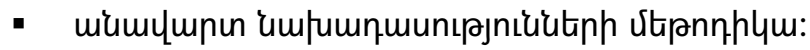

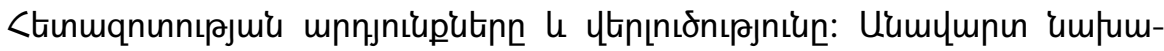

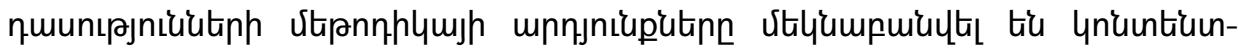

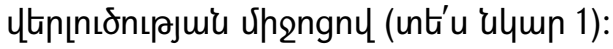

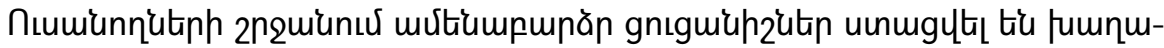

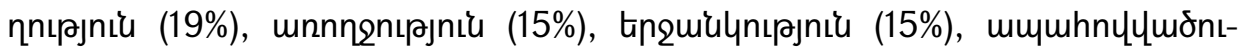

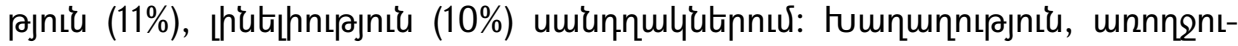

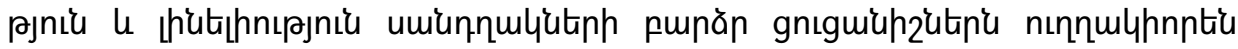
цmщцो

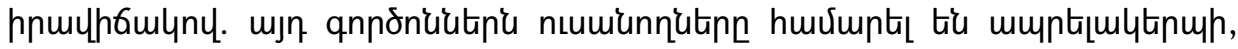

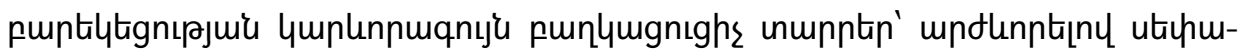

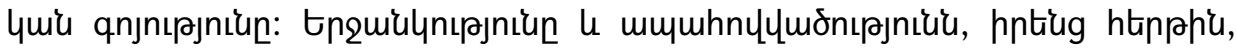

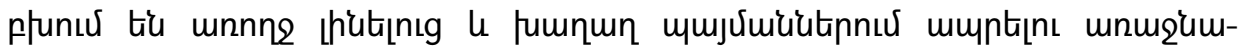
htppnıpjniuhg:

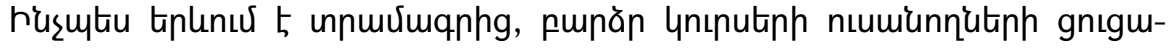

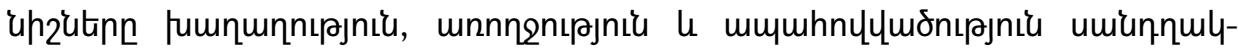

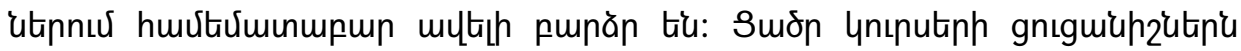

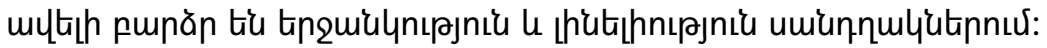




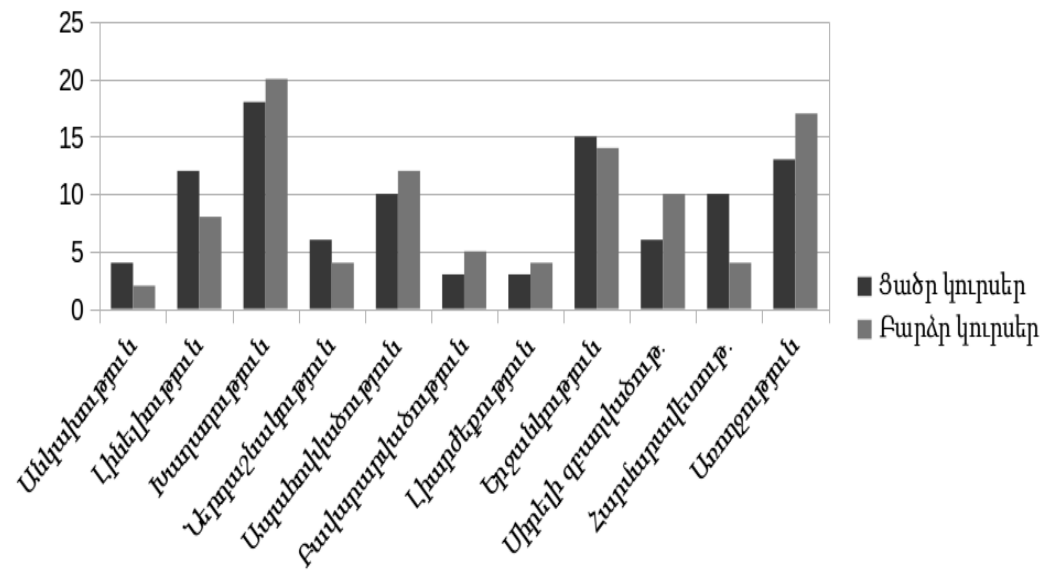

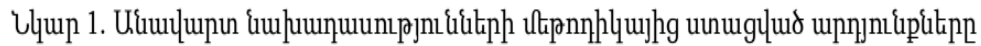

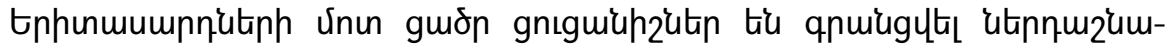

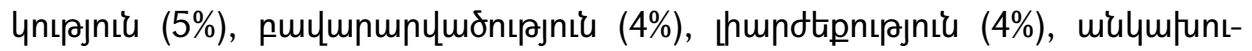

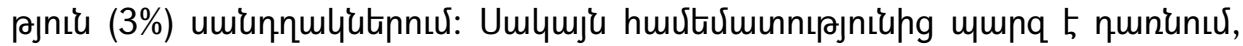

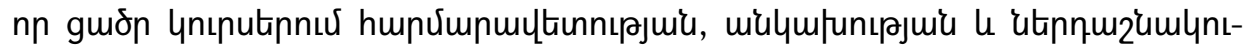

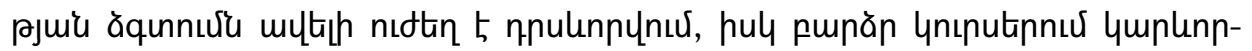

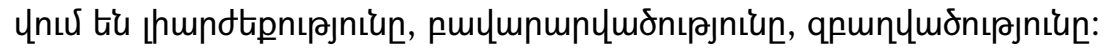

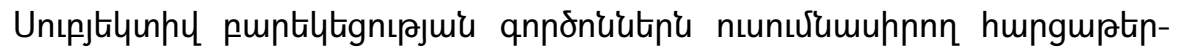

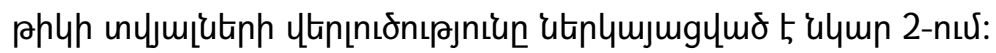
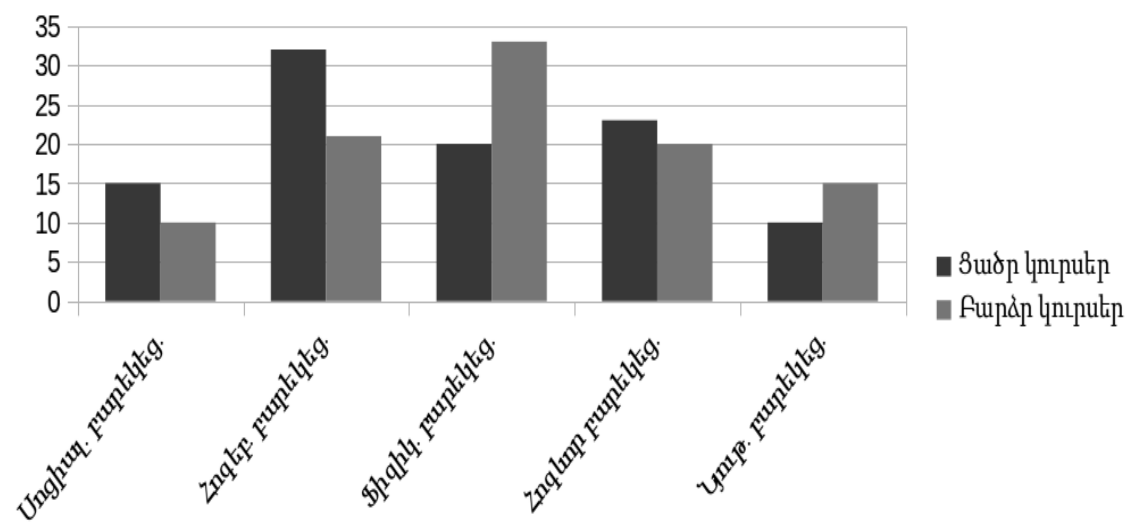

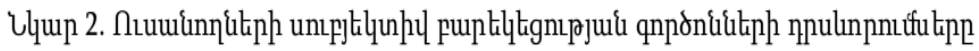

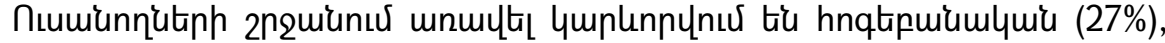

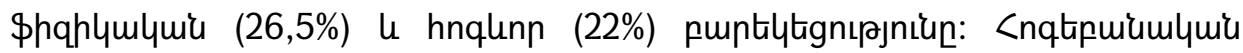

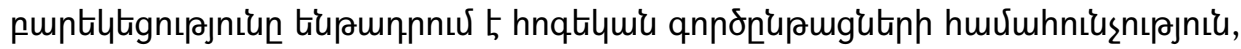

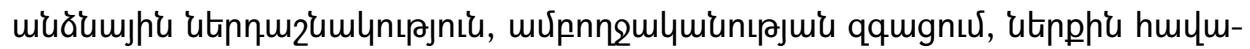

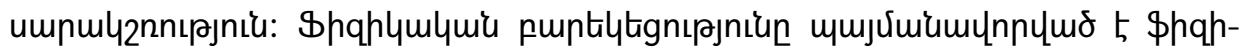




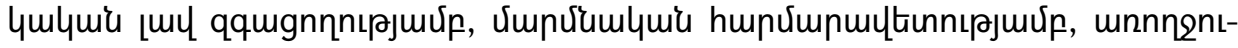

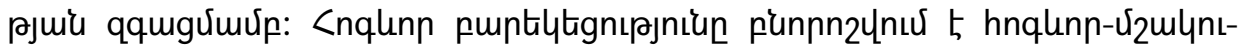

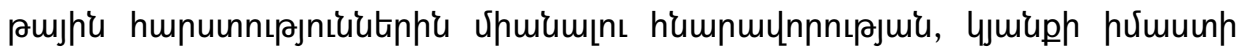

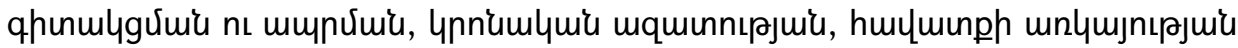
htin:

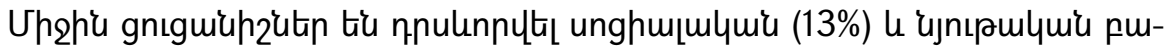

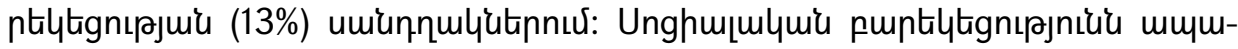

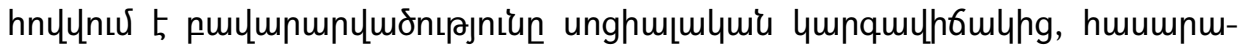

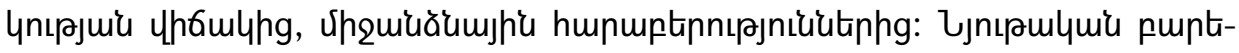

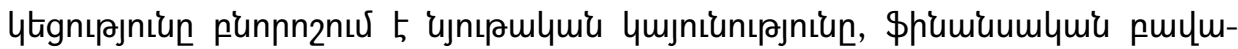

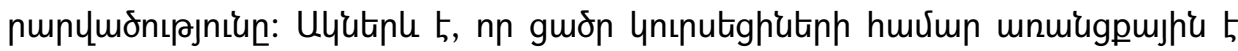

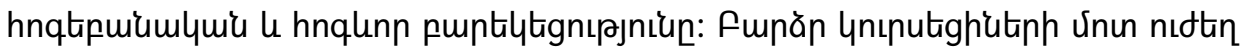

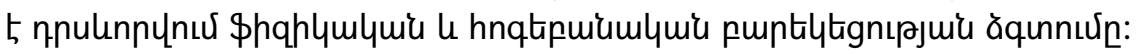

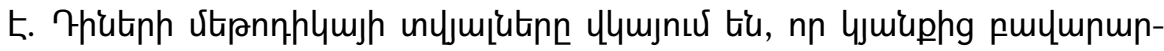

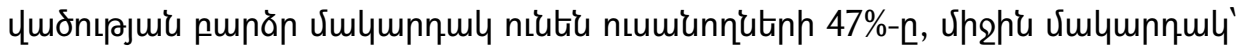

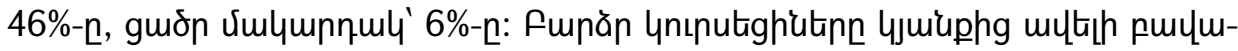

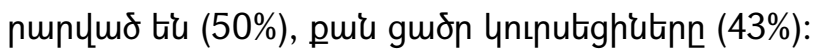

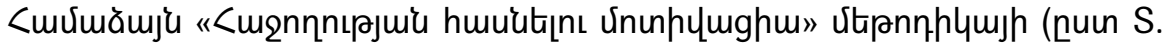

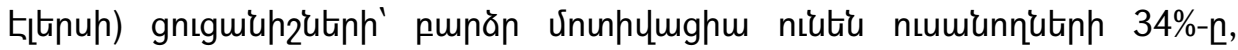

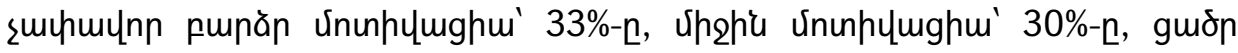

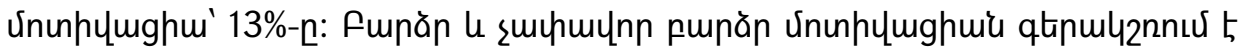

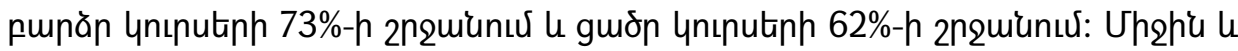

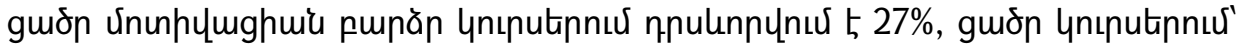

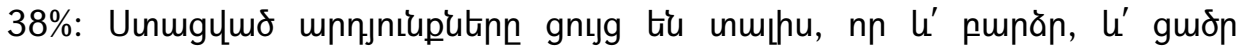

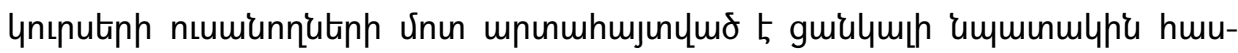

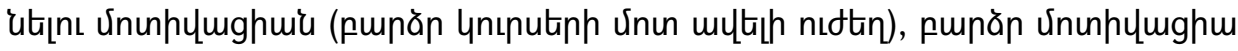

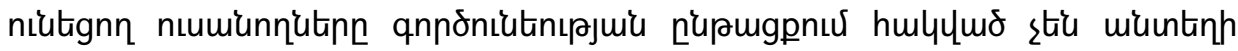

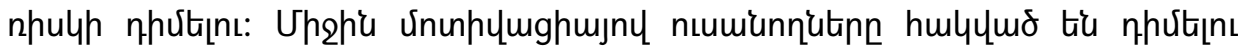

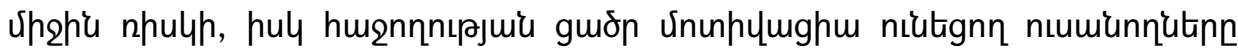

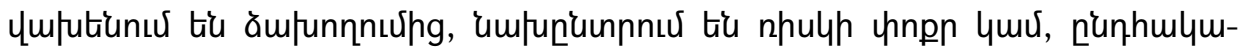

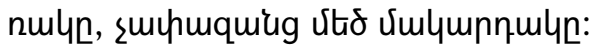

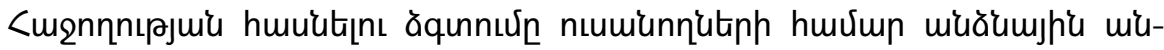

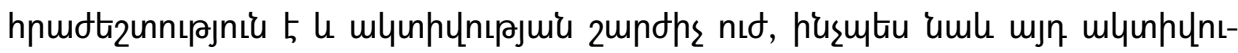

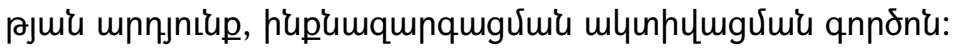

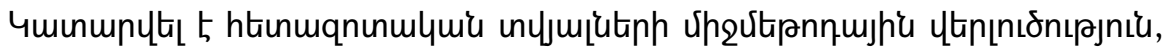

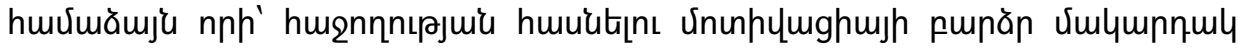

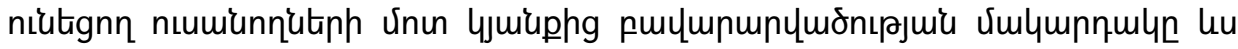

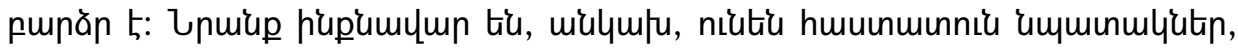

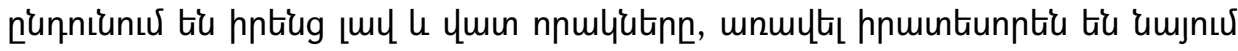

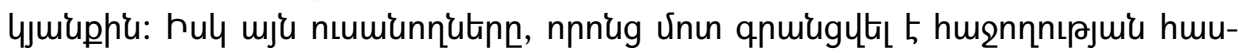




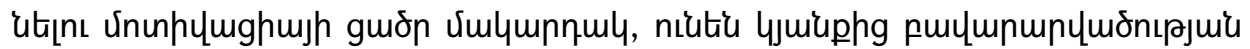

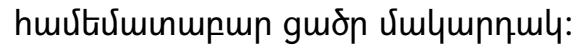

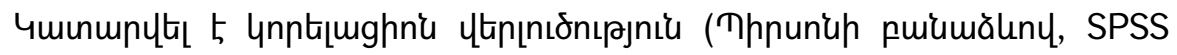

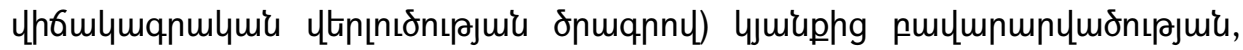

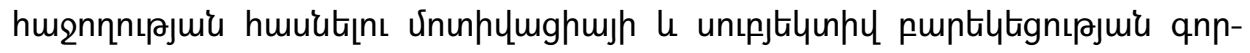

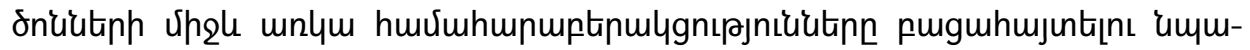

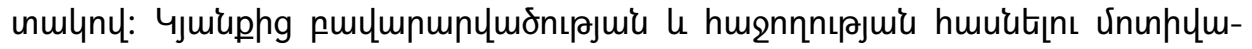

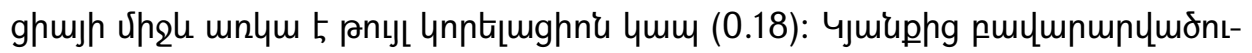

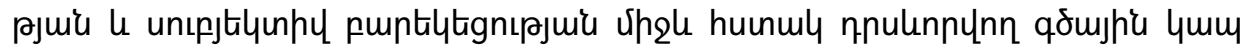

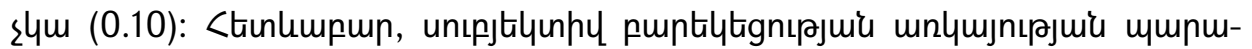

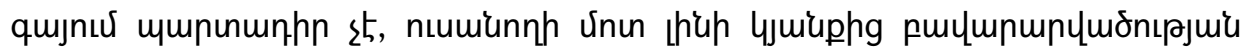

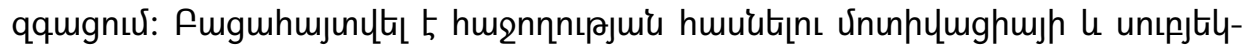

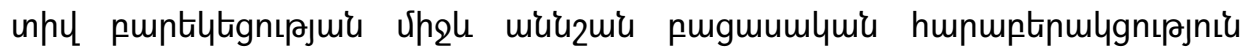
(-0.04):

\section{tqnulyugnıpjnı\&utin:}

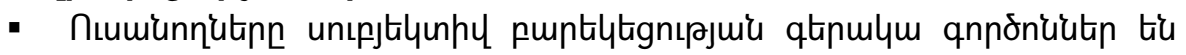

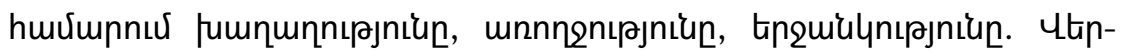

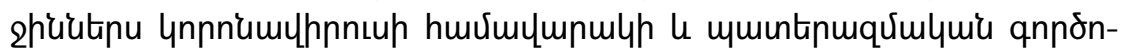

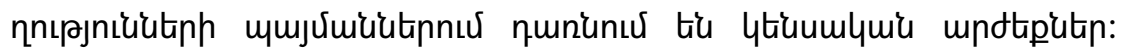

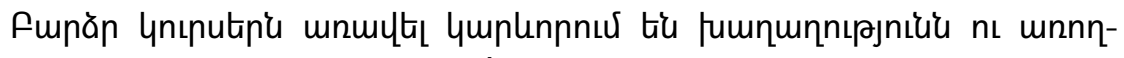

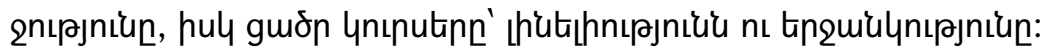

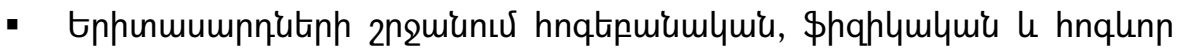

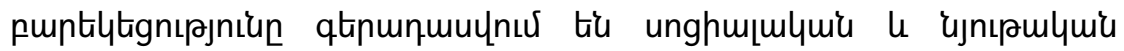

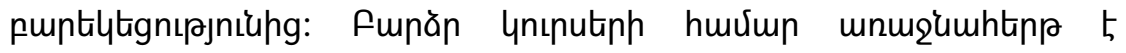

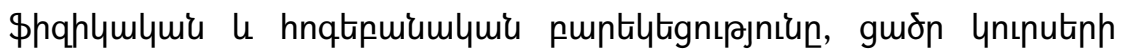
huxump' hnqtipuiumlymiun 4 hnqunnn:

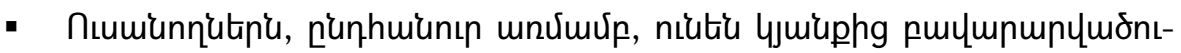

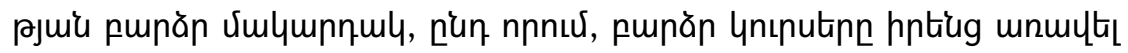

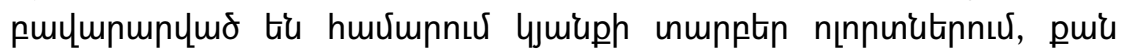

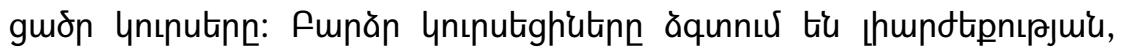

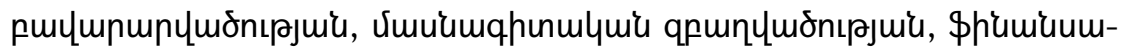

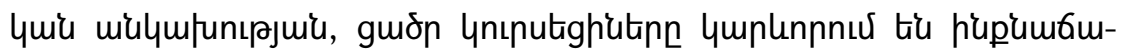

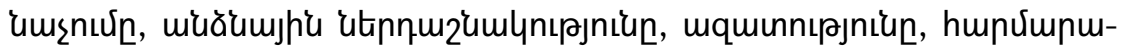

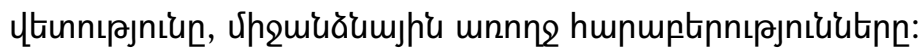

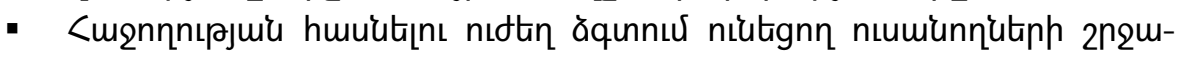

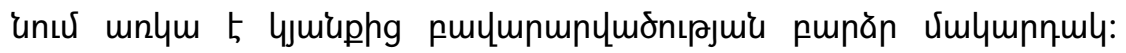

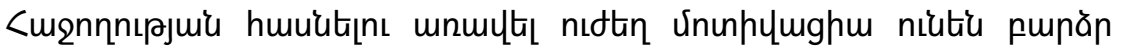

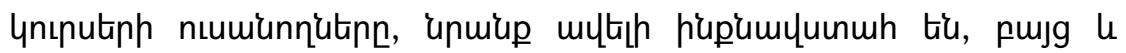
wuhumlh nhulh stü nhưnu: 


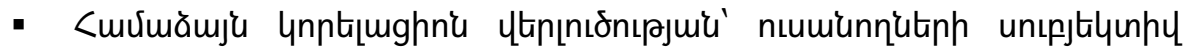

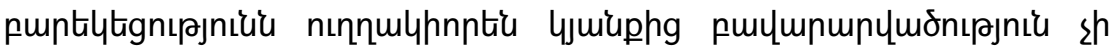

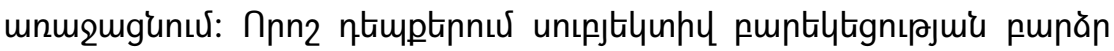

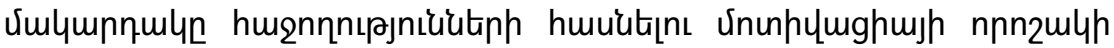
ulumquimis 5 huiuqtigunus:

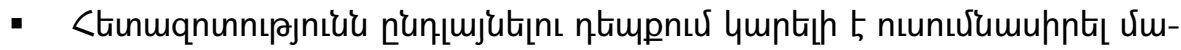
qhuinnnumlymir unpnıpniu uunmgnn niumiunnitiph unıpjtiqunhy

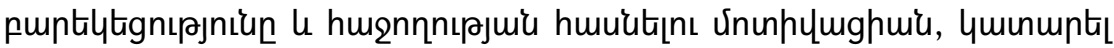

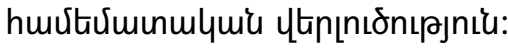

\section{9pulquitunıpjnitu}

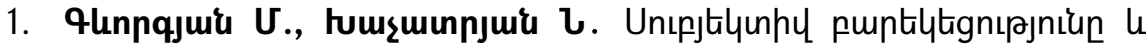

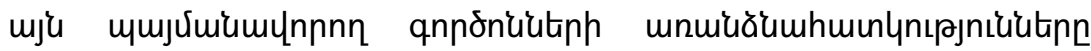

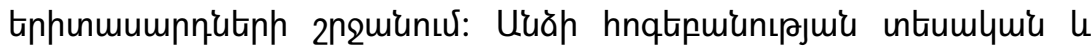
uhnunulyuiu hungtin, tp., 2016, 5,2 153-162:

2. Алимбаева Р.Т., Мартаева А.У. Субъективное благополучие и удовлетворенность жизнью // Инновационная наука. 2016. № 11-3. c. $142-143$.

3. Галиахметова Л.И. Благополучие, субъективное благополучие, удовлетворенность жизнью: проблема взаимосвязи. Вестник Башкирского университета, 2015, № 3. с. 1114-1118.

4. Гриднева О.С. Ориентация на достижение жизненного успеха, как важный фрактор воспитания старшеклассников // Молодой ученый, М., №12, 2013. с. 442-445.

5. Деева Н.А. Жизненная успешность: механизм, свойство, состояние. Контексты понимания// Современные исследования социальных проблем, 2017, Т. 8, № 11. с. 22-46.

6. Долгов Ю.Н. Субъективное благополучие личности в контексте жизненных стратегий// Личность, семья и общество. 2013. Электронный ресурс. Режим доступа: https://cyberleninka.ru/article/n/subektivnoe-blagopoluchie-lichnosti-vkontekste-zhiznennyh-strategiy (20.06.21).

7. Карапетян Л.В. Теоретические подходы к пониманию субъективного благополучия. Известия Уральского федерального университета. 2014, т. 123, № 1. с. 171-182.

8. ОрловаД.Г..Психологическое и субъективное.благополучие: опр еделение, структура, исследования (Обзор современных источников) //Вестник Пермского государственного гуманитарнопедагогического университета. Серия № 1. 2015, с. 28-32. 
9. Пахоль Б.Е. Субъективное и психологическое благополучие: современные и классические подходы, модели и фракторы // Украинский психологический журнал. 2017. № 1. с. 80-104.

10. Швальбе Б., Швальбе Х., Личность, карьера, успех. Психология бизнеса. М.: Прогресс, 1993.

\section{ВЗАИМОСВЯЗЬ МЕЖДУ СУБЪЕКТИВНЫМ БЛАГОПОЛУЧИЕМ И СТРЕМЛЕНИЕМ К УСПЕХУ СТУДЕНТОВ}

Микаелян М. А., Акопян Н. М. (Армянский государственный педагогический университет, Ереван, Армения)

Целью исследования является изучение взаимосвязи между субъективным благополучием и стремлением к успеху студентов младших и старших курсов. Результаты показывают, что самые высокие показатели субъективного благополучия студентов выражаются в шкалах мира, здоровья, счастья, существования, что, очевидно, связано с нынешней ситуацией в Армении обусловленной войной в Арцахе и пандемией коронавируса. Психологическое, физическое и психическое благополучие среди студентов предпочтительнее социального и материального благополучия. У студентов высокая мотивация добиться успеха в достижении желаемой цели. Старшекурсники, в отличие от студентов младших курсов, более удовлетворены всеми аспектами жизни. Мотивация к успеху у старшекурсников выше, чем у студентов младших курсов. Студенты с высоким уровнем мотивации к успеху имеют более высокий уровень удовлетворенности жизнью.

Ключевые слова: субъективное благополучие, стремление к успеху, студент, удовлетворенность жизнью.

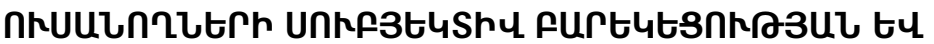

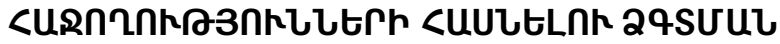

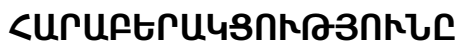

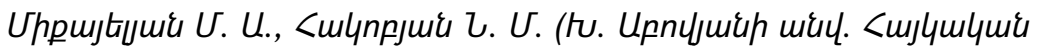

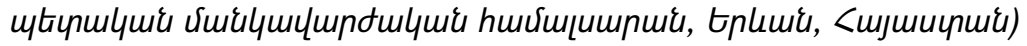

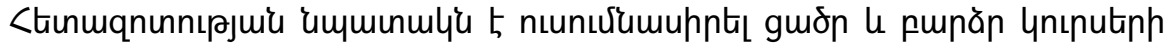

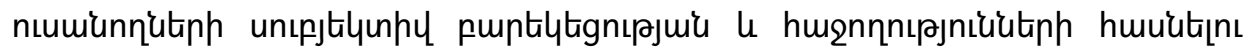

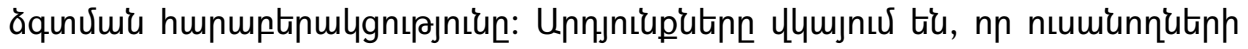

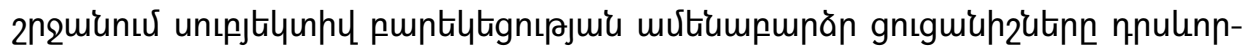

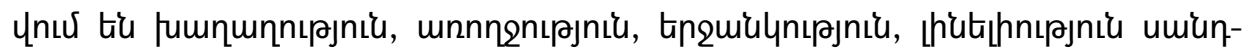

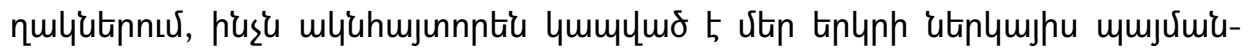




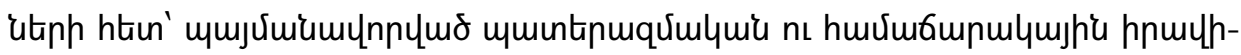

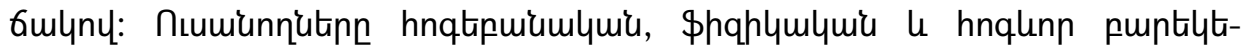

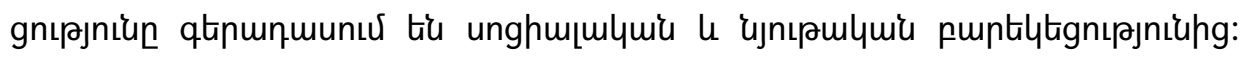

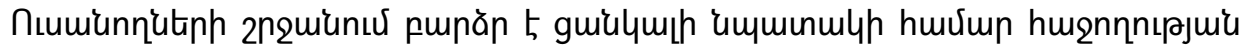

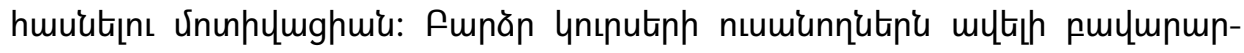

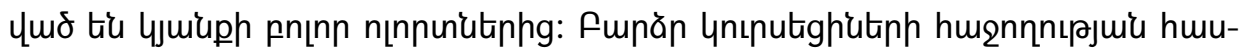

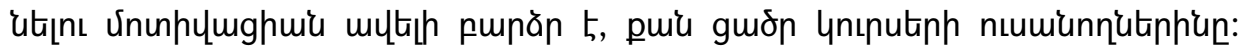

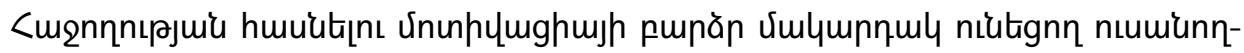

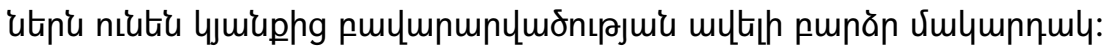

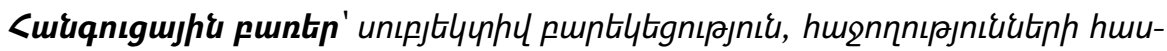

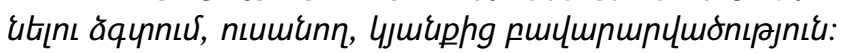

